\title{
Impact of ocean acidification on escape performance of the king scallop, Pecten maximus, from Norway
}

\author{
Burgel Schalkhausser • Christian Bock • \\ Kristina Stemmer • Thomas Brey • \\ Hans-O Pörtner • Gisela Lannig
}

Received: 31 January 2012/Accepted: 23 August 2012/Published online: 30 September 2012

(C) Springer-Verlag 2012

\begin{abstract}
The ongoing process of ocean acidification already affects marine life, and according to the concept of oxygen and capacity limitation of thermal tolerance, these effects may be intensified at the borders of the thermal tolerance window. We studied the effects of elevated $\mathrm{CO}_{2}$ concentrations on clapping performance and energy metabolism of the commercially important scallop Pecten maximus. Individuals were exposed for at least 30 days to $4{ }^{\circ} \mathrm{C}$ (winter) or to $10{ }^{\circ} \mathrm{C}$ (spring/summer) at either ambient $\left(0.04 \mathrm{kPa}\right.$, normocapnia) or predicted future $\mathrm{PCO}_{2}$ levels $\left(0.11 \mathrm{kPa}\right.$, hypercapnia). Cold-exposed $\left(4{ }^{\circ} \mathrm{C}\right)$ groups revealed thermal stress exacerbated by $\mathrm{PCO}_{2}$ indicated by a high mortality overall and its increase from $55 \%$ under normocapnia to $90 \%$ under hypercapnia. We therefore excluded the $4{ }^{\circ} \mathrm{C}$ groups from further experimentation. Scallops at $10{ }^{\circ} \mathrm{C}$ showed impaired clapping performance following hypercapnic exposure. Force production was significantly reduced although the number of claps was unchanged between normocapnia- and hypercapnia-exposed scallops. The difference between maximal and resting metabolic rate (aerobic scope) of the hypercapnic scallops was significantly reduced compared with normocapnic animals, indicating a reduction in net aerobic
\end{abstract}

Communicated by S. Dupont.

B. Schalkhausser $(\varangle) \cdot$ C. Bock · H.-O. Pörtner · G. Lannig Integrative Ökophysiologie, Alfred Wegener Institut für Polar- und Meeresforschung in der Helmholtz-Gemeinschaft, Am Handelshafen 12, 27570 Bremerhaven, Germany e-mail: Burgel.Schalkhausser@awi.de

K. Stemmer · T. Brey

Funktionelle Ökologie, Alfred Wegener Institut für Polar- und Meeresforschung in der Helmholtz-Gemeinschaft, Columbusstrasse, 27570 Bremerhaven, Germany scope. Our data confirm that ocean acidification narrows the thermal tolerance range of scallops resulting in elevated vulnerability to temperature extremes and impairs the animal's performance capacity with potentially detrimental consequences for its fitness and survival in the ocean of tomorrow.

\section{Introduction}

Atmospheric temperature and $\mathrm{CO}_{2}$ concentrations have been rising dramatically over the last decades due to anthropogenic influences (IPCC 2007). In oceans, an increase in dissolved $\mathrm{CO}_{2}$ results in reduced seawater $\mathrm{pH}$ and altered carbonate chemistry, known as ocean acidification (OA). The oceans' average $\mathrm{pH}$ has already declined by more than 0.1 units below the $\mathrm{pH}$ of pre-industrial times (Caldeira and Wickett 2003). If trends continue at current rates, $\mathrm{pH}$ values are predicted to decrease by $0.3-0.4$ units by the end of this century (Orr 2011). These changes will affect a variety of biological processes that depend on $\mathrm{pH}$ and/or the components of the $\mathrm{CO}_{2} /$ bicarbonate/carbonate system. Such effects are predicted to be especially significant for calcifying organisms (Fabry et al. 2008; Doney et al. 2009; Kroeker et al. 2010). Besides the obvious effect on calcification, OA exposure influences the rate of energy metabolism in invertebrates (Langenbuch and Pörtner 2004; Michaelidis et al. 2005; Lannig et al. 2010; Melatunan et al. 2011) via changes in extracellular and, possibly, intracellular $\mathrm{pH}$ values that cause alterations in energy partitioning. At the cellular level (muscle, liver), an extracellular acidosis causes metabolic depression by reducing the rate and costs of acid-base and ion regulation (Pörtner 1987; Pörtner et al. 2000; Pörtner and Bock 2000) and/or of protein synthesis (Langenbuch and Pörtner 2003). 
At whole animal level, this is paralleled either by a decrease (Pörtner et al. 1998; Michaelidis et al. 2005) or by a stimulation in whole organism metabolic rate (Beniash et al. 2010; Stumpp et al. 2011), likely depending on whether and to what extent transepithelial mechanisms of acid-base regulation are depressed or stimulated by OA scenarios (Pörtner et al. 2000). Each of these shifts may result in trade-offs in energy allocation between different biological processes such as ion regulation, calcification, growth or development (Pörtner et al. 2000, 2004; Guderley and Pörtner 2010), possibly leading to constraints in one or more of these processes (Wood et al. 2008; Beniash et al. 2010; Stumpp et al. 2011).

The interactions between ocean acidification and other environmental factors are not well understood, and recent studies suggest a high complexity, with mainly synergistic effects. With respect to temperature, ocean acidification clearly reduced acute heat tolerance of the edible crab, Cancer pagurus $\left(\mathrm{PCO}_{2}\right.$ of $1 \mathrm{kPa}$, Metzger et al. 2007), and narrowed the thermal tolerance range of the spider crab, Hyas araneus, indicated by a $\mathrm{PCO}_{2}$-dependent lowering of the critical temperature of the animals (OA scenarios: 0.07 and $0.3 \mathrm{kPa}$, Walther et al. 2009). A temperature rise of $5{ }^{\circ} \mathrm{C}$ and a $P \mathrm{CO}_{2}$ elevated by $0.1 \mathrm{kPa}$ caused respiration rates and adenylate nucleotide concentrations to fall in the snail Littorina littorea (Melatunan et al. 2011). An OA exposure of $0.3 \mathrm{kPa}$ in combination with acute heat stress (delta $8-11^{\circ} \mathrm{C}$ ) impaired the locomotion capacity of the spider crab, H. araneus (Zittier et al. 2012). In Sydney rock oyster, Saccostrea glomerata, fertilization and larval development was explicitly reduced under hypercapnia (OA scenarios: $0.6,0.7$ and $1 \mathrm{kPa} P \mathrm{PO}_{2}$ ) above optimum temperature (delta $4{ }^{\circ} \mathrm{C}$ ) (Parker et al. 2009). All of these findings indicate that thermal sensitivity is enhanced under projected OA conditions. Conversely, sensitivity to OA is presumably enhanced at thermal extremes. OA exposure also interferes synergistically with other stressors. A study on juvenile oysters Crassostrea virginica revealed that the combined exposure to low salinity (15 vs. $30 \mathrm{psu}$ ) and high $\mathrm{PCO}_{2}(0.07-0.08 \mathrm{kPa})$ produced greater changes in shell properties than each of the factors alone (Dickinson et al. 2012). Internal shell dissolution in Mytilus edulis under hypercapnic conditions was intensified in animals stressed by limited food supply, emphasizing a key role for food and thus energy availability in maximizing resistance to ocean acidification (Melzner et al. 2011).

The concept of oxygen- and capacity-limited thermal tolerance (OCLTT, Pörtner 2002) may offer a suitable approach towards a mechanistic understanding of the synergistic interaction between thermal stress and $\mathrm{OA} / \mathrm{pH}$ effects (Pörtner and Farrell 2008). According to the OCLTT concept, maximal aerobic capacity and thus available metabolic power (energy use per unit time) are limited to the organism's specific thermal tolerance window. As outlined by Guderley and Pörtner (2010), the maximal metabolic power must be partitioned between biological processes. Given that metabolic power depends on environmental parameters such as temperature or $\mathrm{pH}$, environmental conditions outside the optimum range reaching the pejus (= getting worse) and critical range will impair an animal's aerobic scope, resulting in less metabolic power to sustain major fitness-related processes such as growth, reproduction, immune response or the avoidance of predators (see Pörtner 2010; Sokolova et al. 2012).

Our model organism, Pecten maximus, belongs to the family Pectinidae (common name scallops). Scallops are distributed worldwide and are unique among bivalves due to their swimming behaviour. To escape from predators, other bivalves close their valves tightly or use their foot for burrowing and/or somersaults. Due to a reduced foot and shells not tightly closing, scallops use a different escape strategy by fast shell closure or jet-like propulsion enabling them to swim (Wilkens 2006). Given that swimming is used to escape, for example, from predator attacks by starfish or crabs (Winter and Hamilton 1985; Ansell et al. 1991), the scallops' swimming capacity is an important performance parameter. Events of swimming activity have been shown to depend on various biotic (e.g. predator abundance or size/age (Wiborg 1963; Brand 2006) and abiotic factors such as displacement from preferred sites (Winter and Hamilton 1985), effects of currents (Gruffydd 1976) or temperature (Scheibling et al. 1995).

The aim of our study was to investigate the impact of long-term OA exposure on the physiology of the scallop, Pecten maximus, at two temperatures, $4{ }^{\circ} \mathrm{C}$ (winter) versus $10{ }^{\circ} \mathrm{C}$ (spring/summer) against the background of the OCLTT concept. To analyse for energetic trade-offs and associated restrictions in performance capacities under expected OA conditions, we determined clapping performance and oxygen consumption rates under resting and exercise conditions of the commercially important scallop $P$. maximus after long-term incubation at elevated $\mathrm{CO}_{2}$ level.

\section{Materials and methods}

Animals and holding conditions

In February 2011, wild-cultured Pecten maximus (Linnaeus 1758) were obtained from a sea farm (Kvistøy Edelskjell $\mathrm{AS})$ in the northern North Sea near Stavanger $\left(58^{\circ} 58^{\prime} 12^{\prime \prime}\right.$ $\left.\mathrm{N}, 5^{\circ} 42^{\prime} 36^{\prime \prime} \mathrm{E}\right)$. They were collected by scuba divers at a depth of approximately $20 \mathrm{~m}$ and a temperature of $3-5{ }^{\circ} \mathrm{C}$. Environmental mean temperatures at a depth of $20 \mathrm{~m}$ vary 
from 4.5 to $15.2^{\circ} \mathrm{C}$ (monthly means from station Indre Utsira since 2000; data reported by the Institute of Marine Research, http://www.imr.no/forskning/forskningsdata/ stasjoner/dato.php?page $=0 \&$ year=2011\&stid=5869) and ambient $\mathrm{CO}_{2}$ levels of around $390 \mu$ atm (Pfeil et al. 2012).

Animals wrapped in wood wool were transported on ice to the Alfred Wegener Institute by airplane and kept in a recirculated aquarium system at $5{ }^{\circ} \mathrm{C}$. After 2 weeks of recovery, the shells were carefully scrubbed to remove epibionts. The incubations started and all measurements were carried out in March and April 2011 to avoid possible interference with reproduction as the presumable single spawning event takes place in June as shown for P. maximus from Fosen (a location close to Stavanger; Strand and Nylund 1991).

Randomized groups of labelled animals were incubated in recirculating systems in temperature-control rooms at either $4{ }^{\circ} \mathrm{C}$ or at $10^{\circ} \mathrm{C}$ (one system per group, comprising header, receiver and reservoir tanks and 2 experimental tanks (each equipped with 10 animals maximum) similar to the systems described by Michaelidis et al. 2005 or Findlay et al. 2010). Temperature treatments were combined with different $\mathrm{PCO}_{2}$ levels, controls with $\sim 0.039 \mathrm{kPa}$ (390 $\mu \mathrm{atm}$, normocapnia) and elevated exposures with 4 times pre-industrial $P \mathrm{PO}_{2}$ at $\sim 0.112 \mathrm{kPa}$ (1120 $\mu$ atm, hypercapnia). All tanks were continuously bubbled with the specific $\mathrm{CO}_{2}$ concentration that was made using a gas mixing system (HTK, Hamburg, Germany). Incubation lasted a minimum of 33 days up to 60 days (see supplementary materials). According to their suspension-feeding lifestyle, scallops were drip-fed live phytoplankton 3 times per week (DT's Premium Reef Blend (Nannochloropsis osculata, Phaeodactylum, Chlorella, $25.3 \mu \mathrm{g} / \mathrm{L}$ phytoplankton dry weight; Philipp et al. 2008). Feeding lasted for $\geq 6 \mathrm{~h}$ at a concentration of at least $6.10 \times 10^{5}$ cells gram $^{-1}$ bivalve biomass hour $^{-1}\left(4^{\circ} \mathrm{C}\right)$ and $9.15 \times 10^{5}$ cells gram $^{-1}$ bivalve biomass hour ${ }^{-1}\left(10{ }^{\circ} \mathrm{C}\right)$ (water circulation was stopped during feeding times). To ensure good water quality, water of the recirculated systems was exchanged at least twice a week and animal tanks were cleaned from faeces and remaining food items at least 3 times per week. Water physicochemistry was determined at least twice a week to ensure stable conditions (see Table 1): $\mathrm{pH}$ was measured with a $\mathrm{pH}$ electrode (WTW portable $\mathrm{pH}$ meter ProfiLine $\mathrm{pH} 3310$ ) that was calibrated at the respective temperature with NIST buffers and salinity with a conductivity meter (WTW conductivity meter ProfiLine Cond 1970i), and total dissolved inorganic carbon (DIC) was determined with Seal Analysis SFA QuAAtro; pump Technicon trAAcs 800 TM. The pH was converted to total scale via measurement of Dickson standards. $\mathrm{PCO}_{2}$ values were calculated using $\mathrm{CO} 2$ sys (constants of Mehrbach et al. 1973 refitted by Dickson and
Table 1 Physicochemical conditions of seawater after long-term incubations of $P$. maximus during normocapnia and hypercapnia at different temperatures ( 4 and $10{ }^{\circ} \mathrm{C}$ acclimation)

\begin{tabular}{|c|c|c|}
\hline Parameter & Normocapnia & Hypercapnia \\
\hline \multicolumn{3}{|l|}{$4^{\circ} \mathrm{C}$} \\
\hline $\mathrm{PCO}_{2}[\mathrm{kPa}]$ & $0.040 \pm 0.009$ & $0.110 \pm 0.028$ \\
\hline Temperature $\left[{ }^{\circ} \mathrm{C}\right]$ & $3.9 \pm 0.8$ & $3.5 \pm 0.7$ \\
\hline pH (NBS scale) & $8.19 \pm 0.06$ & $7.76 \pm 0.10$ \\
\hline pH (total scale) & $8.08 \pm 0.09$ & $7.65 \pm 0.11$ \\
\hline Salinity [psu] & $31.1 \pm 0.6$ & $31.2 \pm 0.8$ \\
\hline $\mathrm{DIC}[\mu \mathrm{mol} / \mathrm{L}]$ & $2308.5 \pm 47.4$ & $2392.4 \pm 39.3$ \\
\hline \multicolumn{3}{|l|}{$10^{\circ} \mathrm{C}$} \\
\hline $\mathrm{PCO}_{2}[\mathrm{kPa}]$ & $0.040 \pm 0.006$ & $0.115 \pm 0.028$ \\
\hline Temperature $\left[{ }^{\circ} \mathrm{C}\right]$ & $9.8 \pm 0.4$ & $9.6 \pm 0.7$ \\
\hline pH (NBS scale) & $8.25 \pm 0.10$ & $7.81 \pm 0.07$ \\
\hline $\mathrm{pH}$ (total scale) & $8.08 \pm 0.06$ & $7.65 \pm 0.10$ \\
\hline Salinity [psu] & $31.1 \pm 0.7$ & $31.2 \pm 0.7$ \\
\hline $\mathrm{DIC}[\mu \mathrm{mol} / \mathrm{L}]$ & $2315.0 \pm 57.9$ & $2387.3 \pm 40.8$ \\
\hline
\end{tabular}

Data are mean $\pm \mathrm{SD}$ with $N=25-30\left(4{ }^{\circ} \mathrm{C}\right), N=23\left(10^{\circ} \mathrm{C}\right)$

NBS National Bureau of Standards, $\mathrm{PCO}_{2}$ seawater partial pressure of $\mathrm{CO}_{2}$, DIC dissolved inorganic carbon

Millero 1987; programme developed by Lewis and Wallace 1998). Water quality was monitored by measurements of ammonia and nitrite values using photometric test kits (Machery-Nagel, Nanocolor test 0-68 and test 0-03). Animals were starved for $12-24 \mathrm{~h}$ prior to measurements to avoid interference with postprandial metabolism and faeces excretion (Wieser and Medgyesy 1990).

Shell dimensions of the scallops in the different incubation experiments did not differ between groups prior to and after incubation resulting in overall mean $\pm \mathrm{SD}$ of $108.52 \pm 2.44 \mathrm{~mm}$ (height), $94.99 \pm 2.63 \mathrm{~mm}$ (length) and $26.63 \pm 1.88 \mathrm{~mm}$ (width) $(N=44-47)$.

Calculation of condition index

To obtain data about the wellbeing of the animals, we calculated the condition index CI and the muscle index MI after Shiver et al. (2002) and Pazos et al. (1997) as follows:

$C I=\frac{\text { tissue }_{\mathrm{DW}}}{\text { shell }_{\mathrm{DW}}} \cdot 100$

and

$M I=\frac{\text { muscle }_{\mathrm{DW}}}{\text { shell }_{\mathrm{DW}}} \cdot 100$

with DW = dry weight of the total soft tissue and of the adductor muscle, respectively, and of the shell in $[g]$. Dry weights were determined after drying at $75{ }^{\circ} \mathrm{C}$ for as long as no detectable changes in weight were observed. 
Measurement of haemolymph acid-base parameters

Haemolymph parameters were analysed as described in Lannig et al. (2010) using a blood gas analyser (MT 33, Eschweiler, Germany) with glass electrodes for $P \mathrm{CO}_{2}, \mathrm{PO}_{2}$ and $\mathrm{pH}$ that were calibrated at the respective temperature with NIST buffers or calibration gases, respectively.

Scallops were kept on ice and manually immobilized to avoid any claps while carefully sampling about $2 \mathrm{~mL}$ haemolymph out of the tonic adductor muscle with gastight, sterile syringes (0.60-mm cannula). Haemolymph samples were immediately transferred to the blood gas analyser (about $300 \mu \mathrm{L}$ ). For the determination of total $\mathrm{CO}_{2}$ in the haemolymph $\left(\mathrm{C}_{\mathrm{e}} \mathrm{CO}_{2}\right), 200 \mu \mathrm{L}$ of haemolymph were put into glass vials with $3 \mathrm{~mL} 0.1 \mathrm{M} \mathrm{HCl}$ via a microlitre precision syringe (Hamilton, 1700 series) and analysed by a gas chromatograph (Agilent 6890 N GC System, Agilent Technologies, USA). The rest was deep frozen in liquid nitrogen $\left(\mathrm{N}_{2}\right)$ and stored at $-20{ }^{\circ} \mathrm{C}$ for further analysis.

The concentration of apparent bicarbonate in the haemolymph $\left[\mathrm{HCO}_{3}{ }^{-}\right]_{\mathrm{e}}$ was calculated as:

$\left[\mathrm{HCO}_{3-}\right]_{\mathrm{e}}=\mathrm{C}_{\mathrm{e}} \mathrm{CO}_{2}-\left(\alpha \mathrm{CO}_{2} \cdot \mathrm{P}_{\mathrm{e}} \mathrm{CO}_{2}\right)$

with $\mathrm{C}_{\mathrm{e}} \mathrm{CO}_{2}=$ total $\mathrm{CO}_{2}$ concentration $[\mathrm{mM}], \alpha \mathrm{CO}_{2}=$ solubility of $\mathrm{CO}_{2}$ in seawater (calculated from Weiss 1974: $4{ }^{\circ} \mathrm{C}, 31.15$ psu: $0.5610 \mathrm{mmol} \mathrm{L}{ }^{-1} \mathrm{kPa}^{-1} ; 10{ }^{\circ} \mathrm{C}, 31.15$ psu: $\left.0.4583 \mathrm{mmol} \mathrm{L}{ }^{-1} \mathrm{kPa}^{-1}\right), P_{\mathrm{e}} \mathrm{CO}_{2}=$ partial pressure of $\mathrm{CO}_{2}$ in haemolymph [kPa].

After haemolymph sampling, animals were dissected, the wet soft tissues were weighed (to the nearest $0.1 \mathrm{~g}$ ) and tissues samples were freeze clamped and stored in liquid $\mathrm{N}_{2}$ or at $-80{ }^{\circ} \mathrm{C}$ for further analysis.

Measurement of clapping performance

Experimental temperature was adjusted with a thermostat (Julabo, F32-HD), and the respective $P_{C O}$ levels of $\sim 0.039 \mathrm{kPa}$ (normocapnia) and $\sim 0.112 \mathrm{kPa}$ (hypercapnia) were reached by bubbling the water with either air or a mixture of $\mathrm{CO}_{2}$ and air via a multi-gas controller (MKS, PR4000). Determination of clapping performance was carried out following procedures described in previous studies (see Bailey et al. 2003; Fleury et al. 2005 and Guderley et al. 2009).

The measurements were performed using a force gauge (Mecmesin Advanced Force Gauge, $50 \mathrm{~N}$ ). In the experimental tank, scallops were fixed on a plate using a hookand-loop fastener (see Fig. 1 a for experimental set up). The lower valve was additionally immobilized with two clamps and stabilized with dental wax. The force gauge was placed on the front side of the scallop with a hook between its valves at an opening width, which was observed for the undisturbed scallop (between 0.8 and $1.5 \mathrm{~cm}$ depending on the animal). After at least $12 \mathrm{~h}$ of recovery, clapping was induced by introducing aqua dest $_{\text {via }}$ a thin, gas-tight tube into the mantle cavity (see Bailey et al. 2005; Denny and Miller 2006). When the scallop stopped clapping, the stimulation was repeated until animals were fatigue and showed no response to further stimulation (after $\sim 50 \mathrm{~min}$ ). The force of the adductor muscle during time of clapping was measured with a frequency of $10 \mathrm{~Hz}$. The opening width during claps was determined using a ruler and by video analysis (Logitech, Quick Cam E2500).

Force recordings were normalized before each analysis. A "clap" was defined as a short interval of great force difference produced by the scallop with a rapid valve closing via phasic contraction as described in Fleury et al. (2005). Number of claps and force strength were determined from force per time recordings. We calculated the total force $F_{\text {total }}[N]$ of each animal by dividing the "force impulse" (measurement force $[N]$ multiplied by measured time $[\mathrm{s}])$ by total time $[\mathrm{s}]$ :

$F_{\text {total }}=\frac{\int f d t}{t_{\text {total }}}$

$F_{\text {total }}$ is subdivided in a phasic part (force produced by the phasic adductor muscle) and a tonic part (force produced by the tonic muscle). The phasic force $F_{\text {phasic }}[N]$ was calculated as sum of the clap force $F_{\text {clap }}[N]$ (see Fig. 1 b). $F_{\text {clap }}$ is the difference of the maximal force and the starting force during one clap. To calculate the mean phasic force $F_{\text {mean phasic }}[N]$ per one clap, $F_{\text {phasic }}$ was divided by the number of claps:

$F_{\text {meanphasic }}=\frac{\sum_{i}^{n} F_{\text {clap }}}{n}=\frac{F_{\text {phasic }}}{n}$

where the claps are numbered from $\mathrm{i}$ to $\mathrm{n}$.

The tonic force $F_{\text {tonic }}[N]$ was calculated from the difference of $F_{\text {total }}$ and $F_{\text {phasic }}$ :

$F_{\text {tonic }}=F_{\text {total }}-F_{\text {phasic }}=F_{\text {total }}-\frac{\sum_{i}^{n} F_{\text {clap }} \cdot t_{\text {clap }}}{t_{\text {tonic }}}$

where $t_{\text {clap }}$ is the average time per clap $(0.25 \mathrm{~s})$ and $t_{\text {total }}$ is the total measurement time until the animal was fatigued, while $t_{\text {tonic }}$ is the total time of all tonic phases. We calculated with $t_{\text {total }}$ instead of $t_{\text {tonic }}$, which makes a negligible difference of $0.53 \%$, because $t_{\text {tonic }}=t_{\text {total }}-t_{\text {phasic }}$ and $t_{\text {total }} \approx t_{\text {tonic }}$ (with $t_{\text {total }} \sim 3000 \mathrm{~s}$ compared with $t_{\text {phasic }} \sim 16 \mathrm{~s}$ ).

\section{Measurement of metabolic rate}

We measured respiration rates of normocapnia- and hypercapnia-exposed scallops using intermitted flow respirometry (cf. Heilmayer and Brey 2003; Tremblay et al. 
(a)

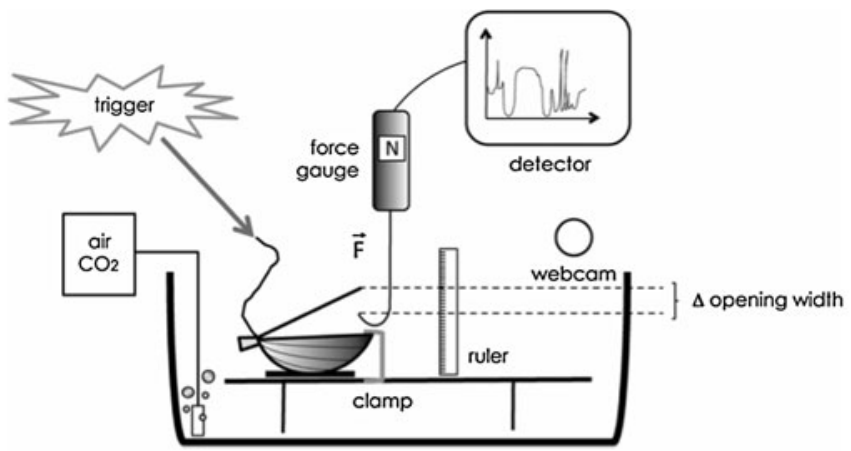

(b)

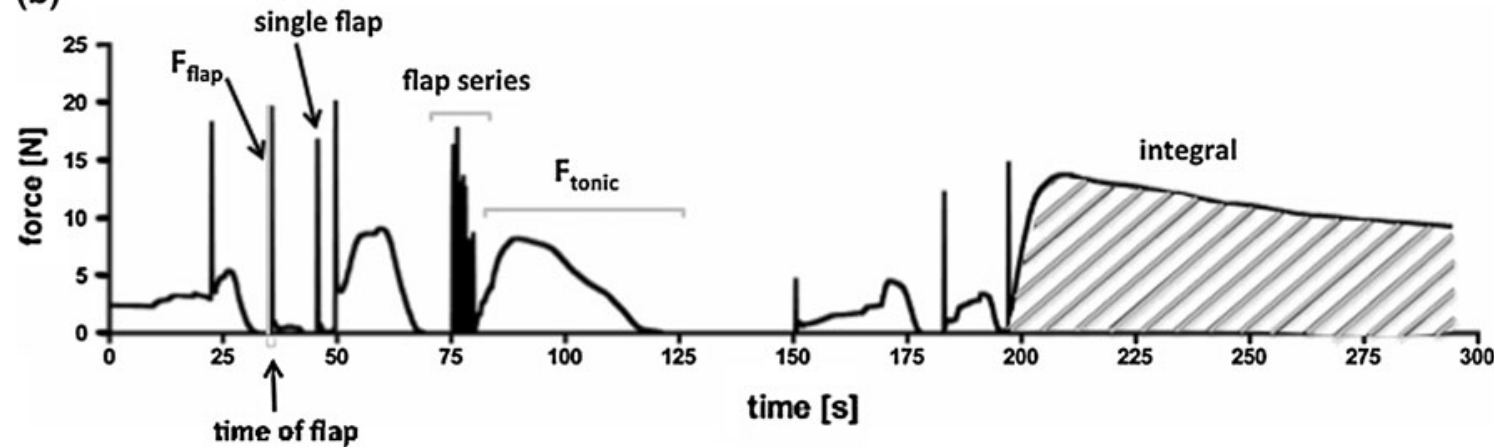

Fig. 1 Scheme of clapping performance data collection on $P$. maximus. a Experimental set up for force measurements. b Example for force recording and visualization of clap force $\left(F_{\text {clap }}\right)$, single

2006). The scallops were placed in respiration chambers (plexiglas chambers with a volume of ca. $1.5 \mathrm{~L}$; one chamber per animal) and immobilized on the bottom of the chamber using hook-and-loop fastener. The respiration chambers were placed into the experimental tank with defined temperature and $\mathrm{PCO}_{2}$ levels (see above). Oxygen saturation was measured with $\mathrm{O}_{2}$ optodes from PreSens (Microx TX2 or TX3, PreSens, Neuweiler, Germany), and continuous water circulation inside the respiratory setup was performed by a peristaltic pump (Ismatec, type Ism404B; Ismatec MCP). In order to exclude animals with potential atypical behaviour without causing disturbances during measurements (similar to Heilmayer and Brey 2003), the scallops were monitored using a web cam under continuous, shaded light. For changes between flowthrough and closed system, plastic quick couplings were used in a different compartment of the experimental tank separated by a water-permeable wall in order to avoid irritations and disturbances for the scallops. Prior to measurements, scallops were allowed to recover for at least $12 \mathrm{~h}$. In each experiment, 3 respiration chambers were used simultaneously. Respiration in empty chambers was measured before and after each experiment to account for potential bacterial respiration (observed values were negligible).

Experimental runs were stopped when oxygen saturation was decreased to $75-70 \%$ inside the chamber. Two to four clap, clap series, tonic force $\left(F_{\text {tonic }}\right)$, time of a clap $\left(t_{\text {phasic }}\right)$, time of a tonic phase $\left(t_{\text {tonic }}\right)$ and part of an integral (see text for details)

runs were measured for each animal within $12 \mathrm{~h}$. During nights, chambers were flooded and connected to the flowthrough system. After measuring the oxygen consumption during resting metabolism, the respiration chambers were opened and the scallops were triggered to swim until fatigue as described above. After exhaustion, chambers were closed and the oxygen consumption measurements were started immediately and recorded until animals regained resting metabolic rates. The dry mass was calculated by applying the conversion factor 0.162 , which was evaluated before using 20 separate $P$. maximus.

We calculated the oxygen consumption $\left(\dot{M}_{\mathrm{O} 2}\right)[\mu \mathrm{mol}$ $\mathrm{O}_{2} \mathrm{~h}^{-1} \mathrm{gDW}^{-1}$ ] of the animal under resting and fatigue conditions as follows:

$\dot{M}_{\mathrm{O} 2}=\alpha_{\mathrm{O} 2} \cdot V_{\mathrm{H} 2 \mathrm{O}} \cdot m \mathrm{DM}^{-1} \cdot \frac{d s\left(\mathrm{O}_{2}\right)}{d t}$

where $\alpha_{\mathrm{O} 2}$ is the oxygen solubility in seawater $\left[\mu \mathrm{mol} \mathrm{O}_{2}\right.$ $\left.\mathrm{L}^{-1} \mathrm{kPa}^{-1}\right], \mathrm{V}_{\mathrm{H} 2 \mathrm{O}}$ is the water volume $[L]$ of the chamber $V_{\text {chamber }}-V_{\text {animal }}, \mathrm{m}_{\mathrm{DM}}$ is the dry mass $[g]$ of the animal and $\mathrm{s}\left(\mathrm{O}_{2}\right)$ is the oxygen consumption [kPa] over time $t[\mathrm{~h}]$.

The net aerobic scope (NAS) [ $\mu \mathrm{mol} \mathrm{O}_{2} \mathrm{~h}^{-1} \mathrm{gDW}^{-1}$ ] was calculated after Fry (1947) as

$N A S=\dot{M}_{\mathrm{O}_{\text {max }}}-\dot{M}_{\mathrm{O} 2_{\text {rest }}}$

where $\dot{M}_{\mathrm{O} 2_{\max }}$ is the maximal metabolic rate (MMR) after exercise and the $\dot{M}_{\mathrm{O} 2_{\text {rest }}}$ is the resting metabolic rate (RMR). 
Statistical analysis

Data sets were analysed using SigmaPlot (Version 12.0, Systat Software, Inc.) and GraphPad Prism (Version 4.0a, GraphPad Software Inc.). Interactions between effects of $\mathrm{CO}_{2}$ exposure and exercise on haemolymph parameters and respiration measurements as well as differences within these groups were considered significant if the probability of Type II error was less than 0.05 using Two Way Analysis of Variance and Two Way Repeated Measures ANOVA, respectively, in combination with a Holm-Sidak Test. Unpaired $t$ test (Mann-Whitney rank sum test if normality test failed) was used to identify significant differences between normocapnia- and hypercapnia-exposed scallops in net aerobic scope (NAS) and for morphological parameters and force measurements. Results are presented in box plots, and values are given as mean \pm SD if not stated otherwise.

\section{Results}

Scallop condition and mortality

From day 20 (normocapnia) and day 38 (hypercapnia) onward, $55 \%$ of normocapnia- and $90 \%$ of hypercapniaexposed scallops died at $4{ }^{\circ} \mathrm{C}$, whereas none of the scallops incubated at $10{ }^{\circ} \mathrm{C}$ died under normocapnic and just one under hypercapnic conditions (see Fig. 2). Condition indices of scallops before and after incubation did not differ between groups with a CI of $11.38 \pm 1.38$ (control group at the start of the experiment, $N=20$ ) and with CIs at the end of the experiment of $11.70 \pm 1.94\left(4{ }^{\circ} \mathrm{C}\right.$ normocapnia, $N=8), \quad 11.24 \pm 0.96\left(10^{\circ} \mathrm{C}\right.$ normocapnia, $N=19)$ and $11.63 \pm 1.35\left(10{ }^{\circ} \mathrm{C}\right.$ hypercapnia, $\left.N=19\right)$

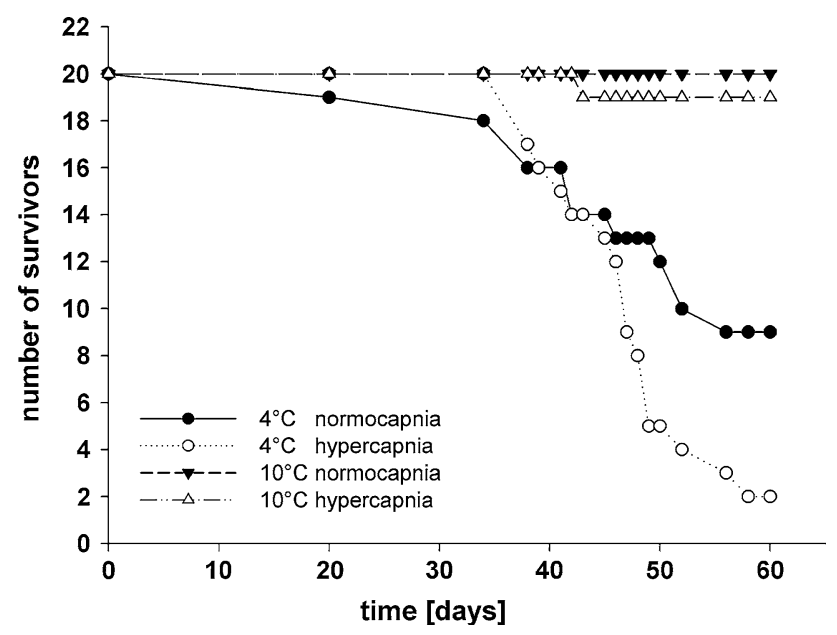

Fig. 2 Survival rate of $P$. maximus after long-term incubation under normocapnia (seawater $\mathrm{PCO}_{2} \sim 0.040 \mathrm{kPa}$ ) and hypercapnia (seawater $\mathrm{PCO}_{2} \sim 0.112 \mathrm{kPa}$ ) at two temperatures $\left(4\right.$ and $10{ }^{\circ} \mathrm{C}$ ), starting with $N=20$ (mean $\pm \mathrm{SD}, F_{2,45}=0.539 ; p=0.587$ ). Muscle indices of scallops after incubation did not differ between groups with $3.66 \pm 0.44\left(4{ }^{\circ} \mathrm{C}\right.$ normocapnia, $\left.N=8\right), 3.34 \pm 0.42$ $\left(10{ }^{\circ} \mathrm{C}\right.$ normocapnia, $\left.N=19\right)$ and $3.61 \pm 0.42\left(10{ }^{\circ} \mathrm{C}\right.$ hypercapnia, $N=19$ ) (mean $\pm \mathrm{SD}, F_{2,45}=2.417 ; p=$ 0.1012 ). Despite similar condition and muscle indices between the two temperature groups, we excluded both normocapnia- and hypercapnia-exposed scallops at $4{ }^{\circ} \mathrm{C}$ from further experimentation due to their stress level at rest as indicated by their high mortality.

Haemolymph acid-base parameters

Following OA exposure at $10{ }^{\circ} \mathrm{C}$, scallops displayed significantly elevated $P_{\mathrm{e}} \mathrm{CO}_{2}\left(F_{1,37}=84.425, p<0.001\right)$, $\mathrm{C}_{\mathrm{e}} \mathrm{CO}_{2} \quad\left(F_{1,36}=42.403, \quad p<0.001\right)$ and $\left[\mathrm{HCO}_{3}{ }^{-}\right]_{\mathrm{e}}$ $\left(F_{1,35}=27.039, p<0.001\right)$ and significantly lowered $\mathrm{pH}_{\mathrm{e}}$ $\left(F_{1,36}=61.861, p<0.001\right)$ values in both groups, resting and fatigued animals (Table 2). After exhaustive exercise, haemolymph values changed in a similar manner irrespective of ambient $\mathrm{CO}_{2}$ level, resulting in significantly lowered $P_{\mathrm{e}} \mathrm{O}_{2} \quad\left(F_{1,36}=28.385, \quad p<0.001\right)$ and $\mathrm{pH}_{\mathrm{e}}$ $\left(F_{1,36}=15.652, p<0.001\right)$ and significantly elevated $P_{\mathrm{e}} \mathrm{CO}_{2}\left(F_{1,37}=35.293, p<0.001\right), \mathrm{C}_{\mathrm{e}} \mathrm{CO}_{2}\left(F_{1,36}=37.968\right.$, $p<0.001)$ and $\left[\mathrm{HCO}_{3}{ }^{-}\right]_{\mathrm{e}}\left(F_{1,35}=23.730, p<0.001\right)$ in

Table 2 Haemolymph parameters of $P$. maximus at rest and after exercise following long-term incubation under normocapnia (seawater $P \mathrm{PO}_{2} \sim 0.040 \mathrm{kPa}$ ) and hypercapnia (seawater $P \mathrm{PO}_{2} \sim 0.112$ $\mathrm{kPa})$ at $10{ }^{\circ} \mathrm{C}$

\begin{tabular}{|c|c|c|}
\hline Parameter & Normocapnia & Hypercapnia \\
\hline \multicolumn{3}{|l|}{ RMR } \\
\hline$P_{\mathrm{e}} \mathrm{O}_{2}[\mathrm{kPa}]$ & $6.52 \pm 1.13$ & $7.95 \pm 2.47$ \\
\hline$P_{\mathrm{e}} \mathrm{CO}_{2}[\mathrm{kPa}]$ & $0.13 \pm 0.02$ & $0.26 \pm 0.06^{*}$ \\
\hline $\mathrm{pH}_{\mathrm{e}}(\mathrm{NBS}$ scale $)$ & $7.67 \pm 0.06$ & $7.42 \pm 0.09^{*}$ \\
\hline $\mathrm{C}_{\mathrm{e}} \mathrm{CO}_{2}[\mathrm{mM}]$ & $1.87 \pm 0.15$ & $2.11 \pm 0.08^{*}$ \\
\hline$\left[\mathrm{HCO}_{3}{ }^{-}\right]_{\mathrm{e}}[\mathrm{mM}]$ & $1.81 \pm 0.15$ & $1.98 \pm 0.06^{*}$ \\
\hline \multicolumn{3}{|l|}{ MMR } \\
\hline$P_{\mathrm{e}} \mathrm{O}_{2}[\mathrm{kPa}]$ & $3.71 \pm 1.06^{+}$ & $4.05 \pm 0.58^{+}$ \\
\hline$P_{\mathrm{e}} \mathrm{CO}_{2}[\mathrm{kPa}]$ & $0.20 \pm 0.05^{+}$ & $0.43 \pm 0.10^{*},+$ \\
\hline $\mathrm{pH}_{\mathrm{e}}(\mathrm{NBS}$ scale $)$ & $7.54 \pm 0.10^{+}$ & $7.32 \pm 0.09^{*},+$ \\
\hline $\mathrm{C}_{\mathrm{e}} \mathrm{CO}_{2}[\mathrm{mM}]$ & $2.10 \pm 0.09^{+}$ & $2.45 \pm 0.16^{*},+$ \\
\hline$\left[\mathrm{HCO}_{3}{ }^{-}\right]_{\mathrm{e}}[\mathrm{mM}]$ & $1.96 \pm 0.05$ & $2.25 \pm 0.13^{*},+$ \\
\hline \multicolumn{3}{|c|}{ Data are mean \pm SD with $N=13-15$ (RMR) and $N=4-5$ (MMR) } \\
\hline \multicolumn{3}{|c|}{$\begin{array}{l}R M R \text { resting metabolic rate, } M M R \text { maximal metabolic rate, } P_{\mathrm{e}} \mathrm{O}_{2} \\
\mathrm{P}_{\mathrm{e}} \mathrm{CO}_{2} \text { extracellular partial pressure of } \mathrm{O}_{2} / \mathrm{CO}_{2}, \mathrm{pH}_{e} \text { extracellular } \\
\mathrm{pH}, \mathrm{NBS} \text { National Bureau of Standards, } \mathrm{C}_{e} \mathrm{CO}_{2} \text { extracellular total } \\
\text { dissolved inorganic carbon, }\left[\mathrm{HCO}_{3}^{-}\right]_{\mathrm{e}} \text { extracellular bicarbonate } \\
\text { concentration }\end{array}$} \\
\hline \multicolumn{3}{|c|}{$\begin{array}{l}\text { Significant differences between normocapnic and hypercapnic data } \\
\text { at same metabolic rate }\end{array}$} \\
\hline \multicolumn{3}{|c|}{$\begin{array}{l}+ \text { Significant differences between RMR and } \mathrm{MMR} \text { at same } \mathrm{CO}_{2} \\
\text { levels }\end{array}$} \\
\hline
\end{tabular}


fatigued compared with resting animals in both normocapnia and hypercapnia groups (Table 2).

Clapping performance and metabolic rate

OA exposure at $10{ }^{\circ} \mathrm{C}$ had no impact on clapping numbers $\left(F_{13,11}=2.512, t_{1,24}=0.0683, p=0.9461\right)$, but a strong effect on force production resulting in significantly lowered total force, mean phasic force and tonic force values $\left(F_{\text {total }}\right.$ : $F_{12,13}=2.788, \quad t_{1,25}=4.776, \quad p<0.0001 ; \quad F_{\text {mean phasic }}$ : $F_{11,11}=1.626, t_{1,22}=3.976, p=0.0006 ; F_{\text {tonic }}: F_{12,13}=$ $2.818, t_{1,25}=4.758, p<0.0001$ ) (Fig. 3). Recovery period and the time until scallops were fatigued were more or less similar in normocapnic and hypercapnic animals.

OA exposure at $10{ }^{\circ} \mathrm{C}$ had no effect on resting metabolic rate (RMR) with medians of $5.10 \mu \mathrm{mol} \mathrm{O} \mathrm{h}^{-1} \mathrm{gDW}^{-1}$ (normocapnia) and $5.27 \mu \mathrm{mol} \mathrm{O} \mathrm{h}^{-1} \mathrm{gDW}^{-1}$ (hypercapnia) (Fig. 4a). After exercise maximal metabolic rate (MMR) was significantly increased above that of the resting animals in both normocapnia- and hypercapniaexposed scallops $\left(F_{1,40}=145.503, p<0.001\right.$; Fig. 4a). However, the exercise-induced increase was lower in the hypercapnia group resulting in a significantly lower MMR $\left(F_{1,40}=4.396, p<0.05\right)$ and net aerobic scope (NAS, Fig. 4b) in hypercapnia- than in normocapnia-exposed animals $\left(F_{8,9}=1.937, t_{1,17}=2.359, p=0.0305\right)$.

\section{Discussion}

\section{Mortality}

In contrast to incubation experiments at $10^{\circ} \mathrm{C}$, we observed a high mortality among scallops exposed to $4{ }^{\circ} \mathrm{C}$
(55\% under normocapnia, $90 \%$ under hypercapnia) (see Fig. 2). This was unexpected as animals had been reared at their winter environmental temperatures of $3-5{ }^{\circ} \mathrm{C}$ (see "Materials and methods"). As water quality (e.g. ammonium/nitrite levels) was similar between incubations, we assume that the high mortality at $4{ }^{\circ} \mathrm{C}$ is related to a timedependent effect: By keeping the animals continually at $4{ }^{\circ} \mathrm{C}$, "physiological wintertime" may have been overextended resulting in enhanced mortality. Against the background of the OCLTT concept, these animals may have been at the lower end of their thermal window too long. Factors reflecting insufficient functional capacity that might have decreased fitness and survival rate in the cold include insufficient food uptake and digestion capacities in the cold as enzymes operate below the thermal optimum (Brock et al. 1986), and/or ciliate beat frequency may be insufficient (Riisgård and Larsen 2007). However, we observed no difference in condition or muscle indices between $4{ }^{\circ} \mathrm{C}$ - and $10{ }^{\circ} \mathrm{C}$-exposed scallops, and our overall means of condition index $(11.48 \pm 1.31, N=46)$ and muscle index $(3.54 \pm 0.48, N=46)$ are comparable to literature data of $P$. maximus showing CIs of 6-10 and MIs of 3-6 in positively growing specimens (Pazos et al. 1997, CI was calculated from reported tissue and shell weights). Similar CI values between 10 and 25 are reported for juvenile bay scallops Argopecten irradians (Shriver et al. 2002). Specific reasons causing enhanced mortality and involving OCLTT capacity limitation (e.g. circulatory limitation) thus remain to be identified. In line with earlier findings on the warm side of the thermal tolerance window (see "Introduction"), our study indicates that OA exposure may have shifted the animals from pejus further to the critical range at the cold side of the thermal tolerance window.
Fig. 3 Data for clapping performance of $P$. maximus after long-term incubation under normocapnia (seawater $\mathrm{PCO}_{2} \sim 0.040 \mathrm{kPa}$ ) and hypercapnia (seawater $\mathrm{PCO}_{2} \sim 0.112 \mathrm{kPa}$ ) at $10{ }^{\circ} \mathrm{C}$. a Total number of claps until fatigue $(N=12-14)$. b Total force $(N=13-14)$. c Mean phasic force $(N=12)$. d Tonic force $(N=13-14)$. Data are depicted in boxplots; asterisk significant differences between normocapnic and hypercapnic data

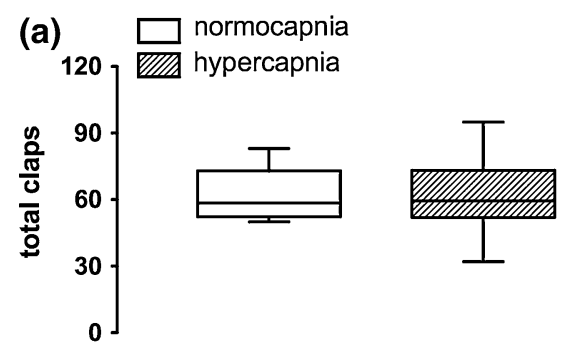

(c)

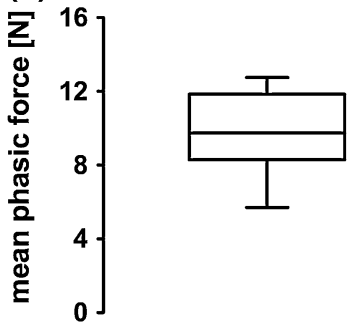

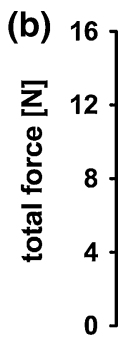
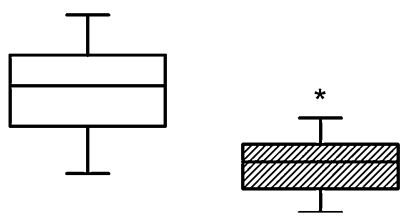

(d)

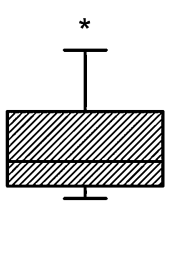

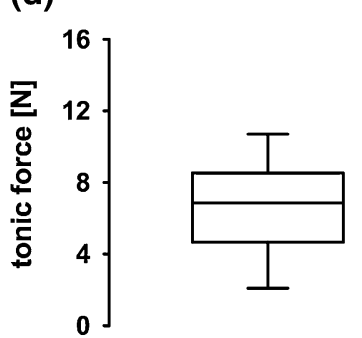

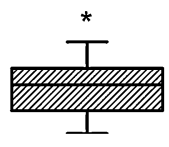


(a)

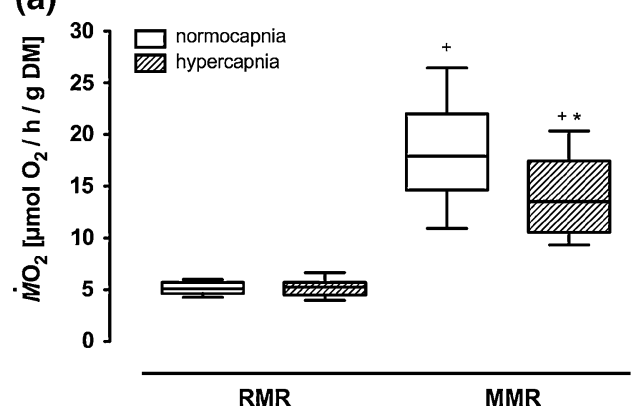

Fig. 4 Oxygen consumption $\left(\dot{M}_{\mathrm{O} 2}\right)$ of P. maximus after long-term incubation under normocapnia (seawater $P \mathrm{CO}_{2} \sim 0.040 \mathrm{kPa}$ ) and hypercapnia (seawater $\mathrm{PCO}_{2} \sim 0.112 \mathrm{kPa}$ ) at $10{ }^{\circ} \mathrm{C}$. a Oxygen consumption at rest (RMR) and after exercise (MMR) $(N=9-13)$.

The hypothesis of cold limited tolerance is further supported by observations by Strand and Brynjeldsen (2003) who reported an extraordinarily high mortality rate (52-100 \%) among juvenile P. maximus along the coast of Norway during an abnormally cold winter (1995/6) at temperatures between 2 and $4{ }^{\circ} \mathrm{C}$. The normal temperature profile experienced by scallops from the Stavanger region since 2000 usually yielded monthly means of $5{ }^{\circ} \mathrm{C}$ at a depth of around $20 \mathrm{~m}$, and during that whole period, there was only 1 month with a mean below $5{ }^{\circ} \mathrm{C}$ (Institute of Marine Research, Norway 2012). Furthermore, scallops survived well for more than 10 months in our aquarium system at $5{ }^{\circ} \mathrm{C}$ supporting our hypothesis that $P$. maximus may have reached its lower thermal limit at around $4{ }^{\circ} \mathrm{C}$ leading to an increase in mortality.

\section{Haemolymph acid-base parameters}

Scallops under hypercapnia had a lower $\mathrm{pH}_{\mathrm{e}}$, a higher $P_{\mathrm{e}} \mathrm{CO}_{2}$, bicarbonate and $\mathrm{C}_{\mathrm{e}} \mathrm{CO}_{2}$ level than normocapnic animals, indicating that $P$. maximus did not compensate for the extracellular acidosis under long-term OA exposure. As already shown in other studies (e.g. Lindinger et al. 1984; Walsh et al. 1984; Michaelidis et al. 2005; Melzner et al. 2009), the capacity for extracellular $\mathrm{pH}$ regulation is low in bivalves, including scallops. Similar to oysters (Lannig et al. 2010), scallops showed a significant, albeit small elevation in bicarbonate concentrations under hypercapnia. This indicates no or only a small degree of compensation of the acid-base disturbance in the haemolymph. Passive compensation depends on the level of non-bicarbonate buffer value that was not determined. Other bivalves, for example, Mytilus edulis, have haemolymph non-bicarbonate buffer lines $\left(\beta_{\mathrm{NB}}=0.4 \mathrm{mmol} \mathrm{L} \mathrm{LH}^{-1} \mathrm{pH}^{-1}\right.$, Booth et al. 1984) similar to seawater $\left(0.3 \mathrm{mmol} \mathrm{L}{ }^{-1} \mathrm{pH}^{-1}\right)$. It seems that in bivalves in general, a $\mathrm{CO}_{2}$ induced acidosis remains largely uncompensated, due to low buffering and limited capacity of proton equivalent ion exchange. (b)

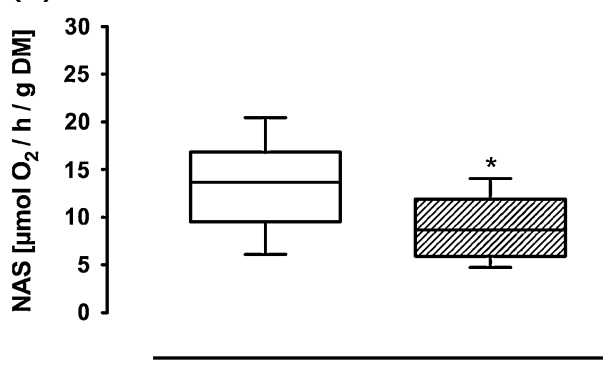

b Net aerobic scope (NAS; $N=9-10$ ). Data are depicted in boxplots; asterisks significant differences between normocapnic and hypercapnic data. ${ }^{+}$significant differences between RMR and MMR

Exhaustive exercise at $10{ }^{\circ} \mathrm{C}$ significantly affected $P$. maximus haemolymph parameters (see Table 2 ). Under both normocapnic and hypercapnic conditions, values of $\mathrm{pH}_{\mathrm{e}}$ and $P_{\mathrm{e}} \mathrm{O}_{2}$ of the fatigued scallops decreased, while $P_{\mathrm{e}} \mathrm{CO}_{2}, \mathrm{C}_{\mathrm{e}} \mathrm{CO}_{2}$ and bicarbonate levels increased compared with findings in resting scallops. The lack of respiratory pigments, the poor perfusion of the adductor muscle and its low mitochondrial density reflect insufficient supply and use of oxygen by the phasic adductor muscle that largely operates anaerobically during swimming (de Zwaan et al. 1980; Thompson et al. 1980). Exercising scallops mainly catabolize phospho-L-arginine and then glycogen stored in their adductor muscle (e.g. Argopecten irradians can use about $23-25 \%$ of the glycogen stored in the adductor muscle, Epp et al. 1988). Glycolysis leads to octopine formation, largely during recovery after swimming (Grieshaber and Gäde 1977; Gäde et al. 1978; Chih and Ellington 1983); succinate formation may result from oxygen deficiency at mitochondrial level. In fact, $P_{\mathrm{e}} \mathrm{O}_{2}$ remains low during recovery, such that scallops initially recover under hypoxic conditions, associated with a rise in $P_{\mathrm{e}} \mathrm{CO}_{2}$ due to insufficient ventilation (MacDonald et al. 2006). An acidosis would thus result from respiratory $\mathrm{CO}_{2}$ accumulation and non-respiratory proton release during anaerobic end product formation in excess of the proton consumption by phospho-L-arginine degradation (Pörtner 1987). The rise in metabolic rate after exhaustive exercise in scallops (see Fig. 4) is due to increased energy demands during glycogen resynthesis and involves the oxidative degradation of anaerobic end products like D-octopine (MacDonald et al. 2006).

Clapping performance and metabolic rate

Present data of around 62 claps until fatigue (independent of $\mathrm{CO}_{2}$ level) fit very well with the 57 claps obtained by Bailey et al. (2003) for P. maximus at $12{ }^{\circ} \mathrm{C}$. As shown by the same study, great differences in clapping performance 
exist between scallop species, regardless of temperature. The authors compared the number of claps until exhaustion of three species, the Antarctic scallop, Adamussium colbecki, and two temperate species, Aequipecten opercularis and $P$. maximus. Each species was measured at its respective habitat temperature and the results varied between 24 claps (A. opercularis, $12{ }^{\circ} \mathrm{C}$ ), 48 claps (A. colbecki, $\left.0{ }^{\circ} \mathrm{C}\right)$ and the mentioned 57 claps $(P$. maximus, $12{ }^{\circ} \mathrm{C}$ ). Fleury et al. (2005) elicited lower values of around 19 claps in the scallop Placopecten magellanicus at $9.5^{\circ} \mathrm{C}$, upon stimulation with starfish for $200 \mathrm{~s}$. However, animals from that study were not taken to fatigue likely leading to an underestimation of the maximum possible clap numbers. Furthermore, the time of collection (season) seems to affect maximal clap numbers as shown by Guderley et al. (2009) where total clap numbers of $P$. magellanicus varied between 23 claps (spring) and 40 claps (autumn), both measured at $12{ }^{\circ} \mathrm{C}$ (close to habitat temperatures).

Our results on clapping performance and aerobic scope indicate an energetic trade-off under OA conditions at the expense of the scope of escape response. Although the number of claps was similar between normocapnic and hypercapnic animals at $10{ }^{\circ} \mathrm{C}$, reduced force capacities in hypercapnic scallops revealed a significantly negative effect of OA exposure (see Fig. 3). The diminished activation of muscle fibres following OA exposure may indicate that ATP-consuming processes were slowed and energy demand reduced, which resulted in an weakened escape response. This effect may be mediated through the lowering of extracellular $\mathrm{pH}$. In muscle tissues of marine invertebrates, extracellular acidosis slows ion exchange and acid-base regulation (Pörtner et al. 2000). The extracellular acidosis thereby mediates a slowing of myosin ATPase and the development of contractile force in muscle tissue (cf. Pörtner 2008). While oxygen consumption during rest (RMR) did not differ between normocapnia- and hypercapnia-exposed scallops at $10{ }^{\circ} \mathrm{C}$, oxygen consumption following exhaustive exercise (MMR) was reduced in hypercapnic compared with normocapnic animals resulting in a significantly reduced net aerobic scope (NAS) by a factor of 1.49 in OA-exposed scallops (see Fig. 4).

The increase in oxygen consumption during exercise indicates enhanced aerobic energy provision on top of anaerobic metabolism. In sessile bivalves, feeding led to the highest oxygen consumption rates (Tremblay et al. 1998). Mackay and Shumway (1980) showed for the pectinid Chlamys delicatula that exercise (escape response) resulted in an even higher postexercise oxygen consumption rate than the rate seen during feeding. Therefore, net aerobic scope (NAS) calculated as the difference between oxygen consumption at rest and after exhaustive exercise can be assumed as the maximal NAS for scallops.
Limitations in functional capacity may be reached when cellular energy levels fall. According to Pörtner et al. (2004), OA-exposed animals would need to invest more energy into acid-base regulation. Our findings of reduced net aerobic scope indicate that OA-exposed animals at $10{ }^{\circ} \mathrm{C}$ reallocated available energy to, for example, ion regulation but at the expense of other processes, for example, activity. In the study of Wood et al. (2008), calcification rates and respiration rates of the brittlestar Amphiura filiformis exposed to hypercapnia were increased, but muscle mass was reduced instead. This "muscle wastage" was seen as a fast and time limited trade-off between structure (morphological integrity) and function (arm movement). In salmon and oysters, exposure to low $\mathrm{pH}$ or elevated $\mathrm{PCO}_{2}$ led to a partial depletion of tissue energy reserves such as glycogen and lipids (Haya et al. 1985; Lannig et al. 2010; Dickinson et al. 2012).

\section{Conclusion}

Our study revealed that ocean acidification narrows the scope for exercise performance of the active calcifier, Pecten maximus. At elevated $\mathrm{CO}_{2}$ levels, clapping force was reduced indicating that this species might become vulnerable to predators as their escape response is weakened following exposure to predicted OA scenarios. Our results seen together with those of other studies indicate that OA-induced energetic trade-offs exist, reducing the energy available for fitness-related processes such as locomotion, growth and/or stress resistance. The increased mortality among scallops exposed to $4{ }^{\circ} \mathrm{C}$ and elevated $\mathrm{CO}_{2}$ levels implies an OA-induced exacerbation of cold stress, in line with a narrowing of the thermal tolerance range at the cold side. Further investigations at the cellular level are necessary to examine the allocation of metabolic power to different processes and to fully unravel the picture of OA-induced impacts on energy metabolism and associated energy reallocations.

Acknowledgments We would like to thank Øivind Strand and the aquaculture Kvitsøy Edelskjell AS for their support in animal supply. We also gratefully acknowledge the support of M. Bullwinkel, $\mathrm{N}$. Klassen and C. Otten, who assisted in animal care and water analysis during the incubation experiments. We thank O. Heilmayer for helpful discussion, Are Olsen for supporting information on $\mathrm{PCO}_{2}$ values around Stavanger and E. Schaum for language check. We thank the two anonymous reviewers and the editor, Sam Dupont, for their constructive comments on the manuscript. Burgel Schalkhausser was funded by the Bundesministerium für Bildung und Forschung (BMBF)-funded project "Biological Impacts of Ocean Acidification" (BIOACID, FKZ 03F0608B). The study is part of the "Polar regions and coasts in a changing Earth system" (PACES) research programme of the Alfred Wegener Institute for Polar and Marine Research. 


\section{References}

Ansell A, Dao JC, Manson J (1991) Three European scallops: Pecten maximus, Chlamys (Aequipecten) opercularis and $C$. (Chlamys) varia. In: Shumway SE (ed) Scallops: biology, ecology and aquaculture, 1st edn. Elsevier, Amsterdam, pp 715-752

Bailey DM, Peck LS, Bock C, Pörtner HO (2003) High-energy phosphate metabolism during exercise and recovery in temperate and Antarctic scallops: an in vivo ${ }^{31} \mathrm{P}-\mathrm{NMR}$ study. Physiol Biochem Zool 76(5):622-633. doi:10.1086/376920

Bailey DM, Johnston IA, Peck LS (2005) Invertebrate muscle performance at high latitude: swimming activity in the Antarctic scallop, Adamussium colbecki. Polar Biol 28:464-469. doi: 10.1007/s00300-004-0699-9

Beniash E, Ivanina A, Lieb NS, Kurochkin I, Sokolova IM (2010) Elevated levels of carbon dioxide affect metabolism and shell formation in oysters Crassostrea virginica. Mar Ecol Prog Ser 419:95-108

Booth CE, McDonald DG, Walsh PJ (1984) Acid-base balance in the sea mussel, Mytilus edulis. I. Effects of hypoxia and air-exposure on hemolymph acid-base status. Mar Biol Lett 5:347-358

Brand AR (2006) Scallop ecology: distributions and behaviour. In: Shumway SE, Parson GJ (eds) Scallops: biology ecology and aquaculture, 1st edn. Elsevier, Amsterdam, pp 651-744. doi: 10.1016/S0167-9309(06)80034-7

Brock V, Kennedy VS, Brock A (1986) Temperature dependency of carbohydrase activity in the hepatopancreas of thirteen estuarine and coastal bivalve species from the North American east coast. J Exp Mar Biol Ecol 103:87-101

Caldeira K, Wickett ME (2003) Anthropogenic carbon and ocean pH. Nature 425:365

Chih CP, Ellington WR (1983) Energy metabolism during contractile activity and environmental hypoxia in the adductor muscle of the Bay Scallop Argopecten irradians concentricus. Physiol Zool 56(4):623-631

de Zwaan A, Thompson RJ, Livingston DR (1980) Physiological and biochemical aspects of the valve snap and valve closure responses in the giant scallop Placopecten magellanicus II. Biochemistry. J Comp Physiol B 137:105-114

Denny M, Miller L (2006) Jet propulsion in the cold: mechanics of swimming in the Antarctic scallop Adamussium colbecki. J Exp Biol 209:4503-4514. doi:10.1242/jeb.02538

Dickinson GH, Ivanina AV, Matoo OB, Pörtner HO, Lannig G, Bock C, Beniash E, Sokolova IM (2012) Interactive effects of salinity and elevated $\mathrm{CO}_{2}$ levels on juvenile eastern oysters, Crassostrea virginica. J Exp Biol 215:29-43. doi:10.1242/jeb.061481

Dickson AG, Millero FJ (1987) A comparison of the equilibrium constants for the dissociation of carbonic acid in seawater media. Deep-Sea Res 34(111):1733-1743

Doney SC, Fabry VJ, Feely RA, Kleypas JA (2009) Ocean acidification: the other $\mathrm{CO}_{2}$ problem. Annu Rev Mar Sci 1:169192

Epp J, Bricelj VM, Malouf RE (1988) Seasonal partitioning and utilization of energy reserves in two age classes of the bay scallop Argopecten irradians irradians (Lamarck). J Exp Mar Biol Ecol 121:113-136

Fabry VJ, Seibel BA, Feely RA, Orr JC (2008) Impacts of ocean acidification on marine fauna and ecosystem processes. ICES J Mar Sci 65:414-432

Findlay HS, Kendall MA, Spicer JI, Widdicombe S (2010) Relative influence of ocean acidification and temperature on intertidal post-larvae at the northern edge of their geographic distribution. Estuar Coast Shelf Sci 86:675-682

Fleury P-G, Janssoone X, Nadeau M, Guderley H (2005) Force production during escape responses: sequential recruitment of the phasic and tonic portions of the adductor muscle in juvenile sea scallop, Placopecten magellanicus (Gmelin). J Shellfish Res 24(4):905-911. doi:10.2983/0730-8000(2005)24[905:FPDERS] 2.0.CO;2

Fry FE (1947) Effects of the environment on animal activity. Univ Toronto biol Ser 55. Pub Ont Fish Res Lab 68:1-62

Gäde G, Weeda E, Gabbott PA (1978) Changes in the level of octopine during the escape responses of the scallop, Pecten maximus (L.). J Comp Physiol 124:121-127

Grieshaber M, Gäde G (1977) Energy supply and the formation of octopine in the adductor muscle of the scallop, Pecten jabobaeus (Lamarck). Comp Biochem Physiol B 58:249-252

Gruffydd LD (1976) Swimming in Chlamys islandica in relation to current speed and an investigation of hydrodynamic lift in this and other scallops. Nor J Zool 24:365-378

Guderley H, Pörtner HO (2010) Metabolic power budgeting and adaptive strategies in zoology: examples from scallops and fish. Can J Zool 88:753-763

Guderley H, Labbé-Giguere S, Janssoone X, Bourgeois M, Pérez HM, Tremblay I (2009) Thermal sensitivity of escape response performance by the scallop Placopecten magellanicus: impact of environmental history. J Exp Mar Biol Ecol 377:113-119

Haya K, Waiwood BA, van Eeckhaute L (1985) Disruption of energy metabolism and smoltification during exposure of juvenile Atlantic salmon (Salmo salar) to low $\mathrm{pH}$. Comp Biochem Physiol C 82(2):323-329

Heilmayer O, Brey T (2003) Saving by freezing? Metabolic rates of Adamussium colbecki in a latitudinal context. Mar Biol 143: 477-484. doi:10.1007/s00227-003-1079-7

IPCC (2007) Climate Change 2007: the physical science basis. Summary for policymakers. Contribution of working group I to the fourth assessment report. The intergovernmental panel on climate change. www.ipcc.ch/SPM2feb07.pdf

Kroeker KJ, Kordas RL, Crim RN, Singh GG (2010) Meta-analysis reveals negative yet variable effects of ocean acidification on marine organisms. Ecol Lett 13:1419-1434

Langenbuch M, Pörtner HO (2003) Energy budget of hepatocytes from Antarctic fish (Pachycara brachycephalum and Lepidonotothen kempi) as a function of ambient $\mathrm{CO}_{2}$ : $\mathrm{pH}$-dependent limitations of cellular protein biosynthesis? J Exp Biol 206: 3895-3903

Langenbuch M, Pörtner HO (2004) High sensitivity to chronically elevated $\mathrm{CO}_{2}$ levels in a eurybathic marine sipunculid. Aquat Toxicol 70:55-61. doi:10.1016/j.aquatox.2004.07.006

Lannig G, Eilers S, Pörtner HO, Sokolova IM, Bock C (2010) Impact of ocean acidification on energy metabolism of oyster, Crassostrea gigas-changes in metabolic pathways and thermal response. Mar Drugs 8:2318-2339. doi:10.3390/md8082318

Lewis E, Wallace DWR (1998) CO2SYS-Program developed for the $\mathrm{CO}_{2}$ system calculations. Carbon dioxide information analysis center; Report ORNL/CDIAC-105, Oak Ridge, Tenn, USA

Lindinger MI, Lawren DJ, McDonald DG (1984) Acid-base balance in the sea mussel Mytilus edulis. Effects of environmental hypercapnia on intra and extracellular acid-base balance. Mar Biol Lett 5:371-381

MacDonald BA, Bricelj VM, Shumway SE (2006) Physiologie: energy acquisition and utilisation. In: Shumway SE, Parson GJ (eds) Scallops: biology, ecology and aquaculture, 1st edn. Elsevier, Amsterdam, pp 417-492. doi:10.1016/S0167-9309(06) 80034-7

Mackay J, Shumway SE (1980) Factors affecting oxygen consumption in the scallop Chlamys deliculata (Hutton). Ophelia 19:19-26

Mehrbach C, Culberson CH, Hawley JE, Pytkowicz RM (1973) Measurement of the apparent dissociation constants of carbonic 
acid in seawater at atmospheric pressure. Limnol Oceanogr 18(6):897-907

Melatunan S, Calosi P, Rundle SD, Moody AJ, Widdicombe S (2011) Exposure to elevated temperature and $\mathrm{PCO}_{2}$ reduces respiration rate and energy status in the Periwinkle Littorina littorea. Physiol Biochem Zool 84(6):583-594. doi:10.1086/662680

Melzner F, Gutowska MA, Langenbruch M, Dupont S, Lucassen M, Thorndyke MC, Bleich M, Pörtner HO (2009) Physiological basis for high $\mathrm{CO}_{2}$ tolerance in marine ectothermic animals: preadaptation through lifestyle and ontogeny? Biogeosciences 6:2313-2331

Melzner F, Stange P, Trübenbach K, Thomsen J, Casties I, Panknin U, Gorb SN, Gutowska A (2011) Food supply and seawater $p \mathrm{CO}_{2}$ impact calcification and internal shell dissolution in the blue mussel Mytilus edulis. PLoS ONE 6(9):e24223. doi:10.1371/ journal.pone. 0024223

Metzger R, Sartoris F, Langenbuch M, Pörtner HO (2007) Influence of elevated $\mathrm{CO}_{2}$ concentrations on thermal tolerance of the edible crab Cancer pagurus. J Therm Biol 32(3):144-151. doi: 10.1016/j.jtherbio.2007.01.010

Michaelidis B, Ouzounis C, Paleras A, Pörtner HO (2005) Effects of long-term moderate hypercapnia on acid-base balance and growth rate in marine mussels Mytilus galloprovincialis. Mar Ecol Prog Ser 293:109-118

Orr JC (2011) Recent and future changes in ocean carbonate chemistry. In: Gattuso J-P, Hansson L (eds) Ocean acidification. Oxford University Press, Oxford, pp 41-66

Parker LM, Ross PM, O'Connor WA (2009) The effect of ocean acidification and temperature on the fertilization and embryonic development of the Sydney rock oyster Saccostrea glomerata (Gould 1850). Glob Change Biol 15:2123-2136. doi: 10.1111/j.1365-2486.2009.01895.x

Pazos AJ, Román G, Acosta CP, Abad M, Sánchez JL (1997) Seasonal changes in condition and biochemical composition of the scallop Pecten maximus L. from suspended culture in the Ria de Arousa (Galicia, N.W., Spain) in relation to environmental conditions. J Exp Mar Biol Ecol 211:169-193

Pfeil B, Olsen A, Bakker DC et al. (2012) A uniform, quality controlled, Surface Ocean CO2 Atlas (SOCAT). Earth system science data (in preparation). http://www.socat.info/. Accessed 29 Mar 2012

Philipp EE, Schmidt M, Gsottbauer C, Sänger AM, Abele D (2008) Size- and age-dependent changes in adductor muscle swimming physiology of the scallop Aequipecten opercularis. Mar Ecol Prog Ser 389:193-202. doi:10.3354/meps08141

Pörtner HO (1987) Contributions of anaerobic metabolism to $\mathrm{pH}$ regulation in animal tissues: theory. J Exp Biol 131:69-87

Pörtner HO (2002) Environmental and functional limits to muscular exercise and body size in marine invertebrate athletes. Comp Biochem Physiol A 133:303-321

Pörtner HO (2008) Ecosystem effects of ocean acidification in times of ocean warming: a physiologist's view. Mar Ecol Prog Ser 373:203-217. doi: $10.3354 / \mathrm{meps} 07768$

Pörtner HO (2010) Oxygen- and capacity-limitation of thermal tolerance: a matrix for integrating climate-related stressor effects in marine ecosystems. J Exp Biol 213:881-893. doi:10.1242/jeb. 037523

Pörtner HO, Bock C (2000) A contribution of acid-base regulation to metabolic depression in marine ectotherms. In: Heldmaier G, Klingenspor M (eds) Life in the cold, 1st edn. Springer, Berlin, pp 443-458

Pörtner HO, Farrell AP (2008) Physiology and climate change. Science 322:690-692

Pörtner HO, Reipschläger A, Heisler N (1998) Metabolism and acidbase regulation in Sipunculus nudus as a function of ambient carbon dioxide. J Exp Biol 201:43-55
Pörtner HO, Bock C, Reipschläger A (2000) Modulation of the cost of $\mathrm{pH}_{\mathrm{i}}$ regulation during metabolic depression: $\mathrm{a}^{31} \mathrm{P}-\mathrm{NMR}$ study in invertebrate (Sipunculus nudus) isolated muscle. J Exp Biol 203:2417-2428

Pörtner HO, Langenbuch M, Reipschläger A (2004) Biological impact of elevated ocean $\mathrm{CO}_{2}$ concentrations: lessons from animal physiology and earth history. J Oceanogr 60:705-718

Riisgård HU, Larsen PS (2007) Viscosity of seawater controls beat frequency of water-pumping cilia and filtration rate of mussels Mytilus edulis. Mar Ecol Prog Ser 343:141-150. doi:10.3354/ meps06930

Scheibling RE, Hatcher BG, Taylor L, Barbeau MA (1995) Seeding trial of the giant scallop (Placopecten magellanicus) in Nova Scotia. In: Lubet P, Barret J, Dao J-C (eds) Fisheries, biology and aquaculture of Pectinids. 8th International Pectinid Workshop, Cherbourg, France, 22nd-29th May, 1991, IFREMER, Actes de Colloques 17:123-129

Shriver AC, Carmichael RH, Valiela I (2002) Growth, condition, reproductive potential, and mortality of bay scallops, Argopecten irradians, in response to eutrophic-driven changes in food resources. J Exp Mar Biol Ecol 279:21-40

Sokolova IM, Frederich F, Bagwe R, Lannig G, Sukhotin AA (2012) Energy homeostasis as an integrative tool for assessing limits of environmental stress tolerance in aquatic invertebrates. Mar Environ Res 79:1-15. doi:10.1016/j.marenvres.2012.04.003

Strand $\varnothing$, Brynjeldsen E (2003) On the relationship between low winter temperatures and mortality of juvenile scallops, Pecten maximus L., cultured in western Norway. Aquacult Res 34: $1417-1422$

Strand Ø, Nylund A (1991) The reproductive cycle of the scallop Pecten maximus (L.) from two populations in Western-Norway, $60 \mathrm{~N}$ and $64 \mathrm{~N}$. In: Shumway SE (ed) An international compendium of scallop biology and culture. Special Publication, World Aquaculture Society, Baton Rouge, pp 95-105

Stumpp M, Wren J, Melzner F, Thorndyke MC, Dupont S (2011) $\mathrm{CO}_{2}$ induced acidification impacts sea urchin larval development I: elevated metabolic rates decrease scope for growth and induce developmental delay. Comp Biochem Physiol A 160:331-340. doi:10.1016/j.cbpa.2011.06.022

Thompson RJ, Livingstone DR, de Zwaan A (1980) Physiological and biochemical aspects of the valve snap and valve closure responses in the giant scallop Placopecten magellanicus I. Physiology. J Comp Physiol 137:97-104

Tremblay R, Myrand B, Guderley H (1998) Thermal sensitivity of organismal and mitochondrial oxygen consumption in relation to susceptibility of blue mussels, Mytilus edulis (L.), to summer mortality. J Shellfish Res 17:141-152

Tremblay I, Guderley HE, Fréchette M (2006) Swimming performance, metabolic rates, and their correlates in the Iceland scallop Chlamys islandica. Physiol Biochem Zool 79(6):1046-1057

Walsh PJ, McDonald G, Booth CE (1984) Acid-base balance in the sea mussel, Mytilus edulis. II. Effects of hypoxia and air-exposure on the intracellular acid-base status. Mar Biol Lett 5:359-369

Walther K, Sartoris FJ, Bock C, Pörtner HO (2009) Impact of anthropogenic ocean acidification on thermal tolerance of the spider crab Hyas araneus. Biogeosciences 6:2207-2215

Weiss RF (1974) Carbon dioxide in water and seawater: the solubility of a non-ideal gas. Mar Chem 2:203-215

Wiborg KF (1963) Some observations on the Iceland scallop Chlamys islandica (Müller) in Norwegian waters. Fiskeridirecktoratets Skrifter. Serie Havunders $ø$ kelser 13:38-53

Wieser W, Medgyesy N (1990) Cost and efficiency of growth in the larvae of two species of fish with widely differing metabolic rates. Proc Biol Sci 242(1303):51-56

Wilkens LA (2006) Neurobiology and behaviour of the scallop. In: Shumway SE, Parson GJ (eds) Scallops: biology, ecology and 
aquaculture, 1st edn. Elsevier, Amsterdam, pp 317-356. doi: 10.1016/S0167-9309(06)80034-7

Winter MA, Hamilton PV (1985) Factors influencing swimming in Bay Scallops, Argopecten irradians (Lamarck, 1819). J Exp Mar Biol Ecol 88:227-242

Wood H, Spicer JI, Widdicombe S (2008) Ocean acidification may increase calcification rates, but at a cost. Proc R Soc Lond B 275:1767-1773
Zittier ZM, Hirse T, Pörtner HO (2012) The synergistic effects of increasing temperature and $\mathrm{CO}_{2}$ levels on activity capacity and acid-base balance in the spider crab, Hyas araneus. Mar Biol. doi:10.1007/s00227-012-2073-8 